\title{
PAYING THE BEARER
}

The BDJ Upfront section includes editorials, letters, news, book reviews and interviews. Please direct your correspondence to the News Editor, Kate Quinlan at the BDJ, The Macmillan Building, 4 Crinan Street, London, N1 9XW or by email to BDJNews@nature.com

Press releases or articles may be edited, and should include a colour photograph if possible.

Stephen Hancocks OBE

Editor-in-Chief

I f you check in your pocket, purse or wallet and find a bank note, on it you will read the words 'I promise to pay the bearer on demand the sum of ... [the quantity of pounds as shown on the note]'. What does that actually mean? In practical terms it has very little meaning at all. It is an historical nicety that harks back to the days when currency was all based on gold. Rather than hike around with heavy metal about your person it was easier to deposit it in a bank and be handed instead a note with a promise on it that the bearer of the note would be paid its face value in gold. I have to tell you that that is no longer the case; please don't try. So why bother? Trust. The trust on which the system of currency is based, worldwide, is that the value of the 'note' is still honoured. Without that trust, without everyone believing in it, the system would be literally and metaphorically worthless.

Trust is also central to the relationship we have with our patients and thankfully the overwhelming indications are that, despite all the mud thrown from various quarters such as from our regulatory body, the General Dental Council (GDC), that trust remains solid. This is an important point in a world in which respect is at a premium. The problem is that when confidence is lost the unravelling of credibility rapidly follows. The socalled 'expenses scandal' a few years ago in relation to the spending of certain members of parliament accelerated the public distrust in politicians and the very recent furore around the tax affairs of the Prime Minister illustrated how

\section{'If so, \\ should the GDC have similar recording facilities in each of our surgeries?'} care workers in a home for elderly people were also in the spotlight for alleged neglect and abuse. Should we, asked the commentators, now insist on 24-hour closed circuit television surveillance of all such sheltered housing accommodation? Really? Is our trust of our fellow humans really so frail that we have to move to this extremity? If so, should the GDC have similar recording facilities in each of our surgeries? Perhaps I shouldn't even suggest this for the Council has, in my opinion, failed utterly once again to 'pay the bearer' by totally undermining the dental profession's trust, and arguably that of the public it purports to protect. In a letter replying to a Freedom of Information request made by Mike Armstrong, Chair of the BDA, the GDC Interim Chief Executive and Registrar takes 13 sides of A4 paper to give answers that would otherwise have remained buried.

The letter indicates that the GDC spent over $£^{1 / 4}$ million on legal costs during a whistleblowing enquiry and a further similar sum in the added costs of staffing changes and public relations, amounting to a total outlay of over $£^{1 / 2}$ million. A £250,000 bill was paid to leading international PR firms for a wide range of services including preparing the Chair and the former Chief Executive for their appearance in front of the Health Select Committee in March 2015. Anyone watching that sitting might reasonably suggest that the Council should ask for its money back - that is, our money back. That level of spending represents the annual retention fees of approximately 562 dentists, or about half the number of new graduates from all UK dental schools in any one year. Money that might not have been levied and instead have been lavished on the dental care of the public.

In a press release Mick Armstrong said, 'This profession wants nothing more than an effective and efficient regulator, but that journey will only begin when the GDC can show it is capable of confronting some hard truths. Sadly, its leadership is unwilling to even start down that road. The Chair has gone to great lengths to absolve the current Council from the sins of the past. A glance at any calendar shows that the bid is futile, as the PSA inquiry into the handling of the whistleblowing issue fell into the time of the current Council. Given the Council's own deliberations in public, these feelings may also not be shared by the other Council members.'

Following on from my previous editorial on the perils of attempting to fool ourselves that we are still living in the 1950s, maybe we should not be surprised by these circumstances. We are in a strong position and so should not only rise above these levels of obfuscation but also hope that one day our regulatory body will genuinely return to the moral currency of paying the bearer and restoring our trust.

DOI: 10.1038/sj.bdj.2016.278 